України] vid 25.05.2011 roku № 583-2011-p.URL: https://zakon.rada.gov.ua/ laws/show/583-2011-\%D0\%BF\#Text. (in Ukrainian).

24. Pro zatverdzhennya hranychnykh norm vytrat na kopiyuvannya abo druk dokumentiv, shcho nadayut'sya za zapytom na informatsiyu, Postanova Kabinetu Ministriv Ukrayiny [On approval of the marginal norms of expenses for copying or printing of documents provided upon request for information: Resolution of the Cabinet of Ministers of Ukraine] vid 13.07 .2011 roku № 740 URL: https://zakon rada gov ua/laws/show/7402011-\%D0\%BF\#Text. (in Ukrainian)

25. Pytannya systemy obliku publichnoyi informatsiyi, Postanova Kabinetu Ministriv Ukrayiny[Issues of public information accounting system,
Resolution of the Cabinet of Ministers of Ukraine] vid 21.11.2011 roku № 1277.URL: https://www.kmu.gov.ua/npas/244787385. (in Ukrainian).

26. Gesetz zur Regelung des Zugangs zu Informationen des Bundes. URL: https://www.gesetze-im-internet.de/ifg/. (in German).

27. Eingriffe in Grundrechte bzw. Menschenrechte. URL: https://www.humanrights.ch/de/ipf/grundlagen/einsteiger-innen/eingriffe/. (in German).

M. Kravchenko, Dr of Law, Senior Researcher

Taras Shevchenko National University of Kyiv, Kyiv, Ukraine

\title{
RIGHT TO INFORMATION: COMMUNICATIVE FREEDOM, SCOPE OF CONSTITUTIONAL PROTECTION, GROUNDS FOR RESTRICTIONS
}

The article is devoted to determining the place of the right to information in the system of communicative freedoms, specifying the scope of constitutional protection and clarifying the criteria for its restriction.

During the research a wide range of general scientific and special-legal methods of scientific knowledge was used, in particular: logical, historical, comparative-legal and system-structural methods of research.

The analysis of domestic and German legal literature on the right to information was important for achieving the goal of the study. The study of the decisions of the Constitutional Court of Ukraine and the decisions of the Federal Constitutional Court of Germany devoted to the interpretation of this fundamental human right was of particular cognitive importance.

As a result of the study, the author states that the right to information belongs to the system of communicative freedoms. As a separate communicative freedom, it actively interacts with other freedoms, such as freedom of expression, freedom of the press, freedom of cinema, and so on. At the same time, the right to information is subordinated to the general goal of communicative freedoms - to be an instrument of communication of an individual with society, a real opportunity to express and convey his views, beliefs and opinions to other individuals.

The right to information protects access to public information not by a particular group of individuals, but by the corresponding right of each individual. In addition, this right should not be construed as a right to restrict access to certain information. Given this, the scope of protection of the right to information is to protect the right of everyone to access information that is in publicly available sources of information. Such information is the source for forming the views and beliefs of individuals. The appropriate approach should be reflected in the following interpretative acts of the Constitutional Court of Ukraine on the interpretation of the right to information.

This fundamental human right may be restricted. However, such interference in the exercise of this right of individuals should not turn into its complete leveling, turning it into fiction. Therefore, along with the purely normative grounds for restricting the right to information, additional criteria are defined according to which each individual case of restriction of this right of individuals must be assessed.

Keywords: information, communication freedom, human rights, sphere of protection, restriction of human rights.

Bulletin of Taras Shevchenko National University of Kyiv.

Legal Studies, 2021; 2 (117): 49-53

УдК: 34:614.2]-048.35

DOI: https:doi.org/10.17721/1728-2195/2021/2.117-9
ISSN 1728-2195

(C) Taras Shevchenko National University of Kyiv,

Publishing center "Kyiv University", 2021

А. Крижевський, канд. іст. наук, асист., мол. наук. співроб. ORCID ID: 0000-0002-7234-7500

Київський національний університет імені Тараса Шевченка, Київ, Україна

\section{АКТУАЛЬНІ ПИТАННЯ ВДОСКОНАЛЕННЯ ЗАКОНОДАВСТВА УКРАЇНИ У СФЕРІ ОХОРОНИ ЗДОРОВ'Я ${ }^{3}$}

Статтю присвячено питанням правового регулювання медичної сфери України. Метоює дослідження актуальних питань удосконалення законодавства України у сфері охорони здоров'я, виявлення наявних проблем та окреслення шляхів їхнього розв'язання. Дослідження правових явищ і юридичних категорій здійснювалося завдяки використанню загальнонаукових і спеціально-правових методів пізнання, а саме: метод класифікації, моделювання, конкретностатистичний, системно-структурний, порівняльно-правовий, формально-юридичний, діалектичний та інші методи наукового аналізу відповідно до предмета дослідження. Стверджується, що для ефективного реформування медичної галузі та для належного захисту прав і свобод суб'єктів правовідносин у сфері охорони здоров'я необхідна якісна нормативно-правова база. Доведено, що вдосконалення чинного законодавства у сфері охорони здоров'я ускладнюється комплексним характером правовідносин у цій галузі та відсутністю чіткого, системного підходу. Обґрунтовано доцільність видання спеціального зведеного законодавчого акта з чіткою внутрішньою структурою - Медичного кодексу України. Автором запропоновано внесення змін до положень, що регулюють питання захисту персональних даних, епідеміологічного нагляду й інфекційного контролю. Обґрунтовано важливість прийняття закону про лікарське самоврядування та вироблення сучасних галузевих стандартів надання медичної допомоги. Проаналізовано проблеми кадрового забезпечення галузі, а відсутність стратегічних документів щодо підготовки медичних працівників і недосконалі посадові інструкиії для керівного персоналу некомериійних закладів охорони здоров'я визначено основними проблемами кадрової політики у сфері охорони здоров'я. Зазначено необхідність поєднання зусиль науковців $i$ практиків у сфері медицини та юриспруденції для розв'язання окреслених проблем удосконалення нормативноправової бази у сфері охорони здоров'я.

Ключові слова: медична реформа, охорона здоров'я, нормативно-правовий акт, законодавство, Медичний кодекс, лікарське самоврядування, медичний стандарm, COVID-19, декларація.

ВСТУП. Головною метою будь-якої системи охорони здоров'я $€$ надання доступної та якісної медичної допомоги, медичних послуг і медичного обслуговування. Головною ціллю держави є побудова ефективної моде- лі системи охорони здоров'я, здатної поліпшити рівень здоров'я населення. В Україні розпочалася медична реформа із прийняття Закону України "Про державні фінансові гарантії медичного обслуговування населен-

\footnotetext{
${ }^{3}$ Наукове дослідження проведено в межах держбюджетної теми № 19БФ042-01М "Соціально-правові засади збереження та розвитку трудового потенціалу України".
} 
ня" від 19.10.2017 р. № 2168-VIII. Проте ресормувати галузь слід із належним нормативним підґрунтям, аби відреформована конструкція міцно стояла й гарантувала безпечну, доступну і якісну медичну допомогу. Незважаючи на значну кількість нормативно-правових актів у сфрері охорони здоров'я в Україні, у своїй сукупності правова база цієї галузі далека від ідеалу, у ній є численні колізії, а деякі моменти взагалі не мають належного правового регулювання.

Метою cmammi є дослідження актуальних питань удосконалення законодавства України у сфері охорони здоров'я, виявлення наявних проблем та окреслення шляхів їхнього розв'язання.

Об'єктом дослідження є правовідносини у сорері охорони здоров'я в Україні.

Методи дослідження. Аналіз правових явищ і юридичних категорій здійснено завдяки використанню загальнонаукових і спеціально-правових методів пізнання, застосування яких зумовлене метою, завданнями та специфікою предмета дослідження. Формальноюридичний метод став основою для аналізу нормативно-правових актів у сфері охорони здоров'я. Порівняльно-правовий дозволив з'ясувати можливість застосування зарубіжного досвіду фрнкціонування системи охорони здоров'я в Україні. Діалектичний метод використовувався для з'ясування сучасного стану правового регулювання відносин у сфері охорони здоров'я, а також визначення перспектив його подальшого розвитку та вдосконалення. У роботі також застосовано метод класифікації, метод моделювання, конкретностатистичний та інші методи наукового аналізу відповідно до предмета дослідження.

Аналіз останніх публікацій. У статтях І. Демченка [1] та Р. Майданика [2] розглянуто особливості класифрікації та систематизації законодавства у сфері охорони здоров'я. Роботи Т. Савіної [3], В. Короленка та Т. Юрочко [4] стосуються особливостей кадрової політики в цій сфрері, а дослідження Л. Заморської [5] та М. Аніщенка [6] - наявних проблем у ході реформування охорони здоров'я. Регулюванню правовідносин у системі охорони здоров'я з позицій адміністративного права присвячено дисертацію С. Книша [7]. Таким чином, аналіз досліджень, дотичних до об'єкта та предмета цієї статті, показав, що проблема вдосконалення нормативно-правової бази у сфері охорони здоров'я залишається досить дискусійною й актуальною, а більшість аспектів проблеми не можна вважати остаточно вирішеними.

ВИКЛАД ОСНОВНОГО МАТЕРІАЛУ. ОХороНа ЗДОров'я - поняття достатньо широке і стосується не лише функціонування національної медичної системи. Система охорони здоров'я - це комплекс заходів, що здійснюються органами державної влади й органами місцевого самоврядування, закладами охорони здоров'я, фрізичними особами-підприємцями. До охорони здоров'я належать також питання підтримання і збереження здоров'я, популяризації здорового способу життя, усвідомлення власної відповідальності громадян за своє здоров'я. Чи не найважливішою проблемою системи охорони здоров'я є законодавча, оскільки лише за наявності якісної правової бази можна розраховувати на належну реалізацію права на охорону здоров'я.

Згідно з ієрархією системи нормативних актів, систему законодавства у сфері охорони здоров'я становлять п'ять рівнів нормативно-правових актів: 1) Конституція України; 2) галузеві кодекси; 3) Закон України "Основи законодавства України про охорону здоров'я" як основний (базовий) закон у сфрері охорони здоров'я; 4) спеціальні закони, що регулюють окремі сфери медичної діяльності; 5) акти центральних і місцевих органів державної виконавчої влади. За рівнями правового регулювання законодавства у сфері охорони здоров'я можна виокремити національне законодавство, нормативно-правові акти, що ухвалюються місцевими органами державної влади або органами місцевого самоврядування, й акти, що ухвалюються в межах закладу охорони здоров'я. Науковці зазначають, що, у зв'язку з великою чисельністю нормативно-правових актів і значною кількістю суб'єктів їх видання, сьогодні у сфері охорони здоров'я існує багато колізій і проблем [8, с. 47].

3 огляду на вищезазначене, з погляду правового регулювання сфера охорони здоров'я має комплексний характер, що зумовлюється наявністю і приватних, і публічних правовідносин та унеможливлює поширення на ці правовідносини норм якоїсь однієї фундаментальної галузі права. Регулювання сфери охорони здоров'я нормами різних галузей права (цивільного, адміністративного, конституційного, трудового тощо) ускладнює процес удосконалення законодавства цієї сфери.

Окрім цього, за 30 років незалежності здійснено декілька масштабних спроб реформування національної системи охорони здоров'я. Однак, як справедливо зазначає Р. Майданик, зміни до законодавства у сфрері охорони здоров'я вносилися безсистемно [2, с. 67]. Держава так і не спромоглася побудувати чітку політику в галузі охорони здоров'я з відповідною стратегією реформування як самої медичної системи, так і нормативно-правових актів, що її регулюють. Хоча спроби і були. Таким чином, удосконалення законодавства у сфрері охорони здоров'я, усунення численних колізій і поліпшення регулювання правовідносин у цій сфері ускладнюються комплексним характером правовідносин і відсутністю державних стратегічних документів.

Розв'язання частини проблем регулювання правовідносин у сфері охорони здоров'я можливе завдяки продуманому нормопроєктуванню. Відсутність системного підходу до оновлення та впорядкування нормативної бази накладає негативний відтінок на ключові суб'єкти системи охорони здоров'я. Удосконалення й оновлення нормативної бази має проводитися з урахуванням особливостей національного менталітету й обраної законодавчої стратегії. Тому з огляду на багаторівневість нормативно-правових актів у сфері охорони здоров'я, величезну кількість суб'єктів їх видання та широкої сорери застосування вважаємо за необхідне провести кодифікацію законодавства у сфері охорони здоров'я і створити Медичний кодекс. Це допоможе швидко очистити законодавство від застарілих норм і сприятиме якісному правовому регулюванню відносин між пацієнтами, закладами охорони здоров'я, страховими компаніями та державою, сприятиме зменшенню прогалин й контроверзій у нормативному забезпеченні. Медичний кодекс для пацієнтів стане гарантією у випадках порушення медичним персоналом права на охорону здоров'я, буде засобом захисту прав медичних працівників, закріплюючи правові основи їхньої діяльності, а також буде основним орієнтиром для юристів у випадку вирішення медичних справ [9, с. 22].

Іншою важливою прогалиною в системі охорони здоров'я $€$ відсутність стандартів надання лікарської допомоги. Про приведення українських стандартів у відповідність 3 аналогічними європейськими зразками йдеться давно. 28.02.2020 р. прийнято Наказ Міністерства охорони здоров'я (далі - МО3) № 590 [10], який мав скасувати численні вітчизняні стандарти. Набрати чинності він повинен був через рік, 01.03.2021 р., а за цей час MO3 планувало підготувати новий перелік галузевих стандартів медичної допомоги, необхідних для виконання програми медичних гарантій, передбачених медичною рефрормою. Однак у зв'язку з пандемією COVID-19 МО3 видала Наказ № 337 від 24.02.2021 р., яким відтермінувала скасування близько 90 докумен- 
тів, що регулюють галузеві стандарти медичної допомоги, до 1 вересня 2021 р. Якщо до 01.09.2021 р. МО3 не напрацює стандартів, то система охорони здоров'я залишиться без стандартів надання медичної допомоги. Наприклад зазначимо, що сьогодні кесарський розтин медичні працівники здійснюють без стандарту, адже Наказ МОЗ від 27.12.2011 р. № 977 утратив чинність ще 08.05.2014 р. [11].

Іншою стороною важливості існування сучасних стандартів і протоколів надання медичної допомоги, розроблених на основі світового досвіду, $є$ покращення правового захисту медичних працівників і пацієнтів. Відповідно до них можна визначити обсяги та методи лікування того чи іншого захворювання, установити обов'язки медичних працівників у процесі надання медичної допомоги, захистити їх від безпідставних звинувачень або ж притягувати до відповідальність за порушення чи халатність.

Ще однією прогалиною в законодавстві, як зазначає Л. Заморська [5], є відсутність права на повторну чи додаткову експертизу за Кримінальним процесуальним кодексом України, в якому не визначено статус повторної експертизи і тому таке право виводиться зі ст. 4 Закону України "Про судову експертизу". Окрім того, у КПК відсутні визначення понять первинної, додаткової, повторної, комісійної та комплексної експертиз. Це не дозволяє на практиці встановити правильність надання медичної допомоги у випадках притягнення до кримінальної відповідальності медичних працівників за "професійні правопорушення", оскільки для цього необхідно провести комісійну судово-медичну експертизу, а часом і не одну.

Зазначимо, що після прийняття Закону України "Про державні фрінансові гарантії медичного обслуговування населення" від 19.10.2017 р. № 2168-VIII [12] в Україні розпочалося реформування сфери охорони здоров'я. Однак на розгляді в Конституційному Суді України перебуває конституційне подання 59 народних депутатів України від 07.02.2018 р. щодо конституційності цього закону. 3 огляду на неоднозначні рішення Конституційного Суду щодо антикорупційного законодавства, прийняті в кінці 2020 р., доля головного нормативноправового акта у сфері реформування системи охорони здоров'я викликає велике занепокоєння. Для української системи охорони здоров'я закінчення розгляду вказаного конституційного подання може бути знаковим. Однак поки що цей документ чинний, на його основі відбуваються реформи в медичній системі, і він став джерелом цілої низки правових проблем, які законодавцю необхідно усунути.

Наприклад, однією з головних цілей медичної реформи $є$ зміна принципів фрінансування галузі. Однак весною 2020 р., відразу після старту II етапу реформи, який передбачав зміни у вторинній ланці, стало зрозуміло, що під час розробляння концепції реформи не було враховано можливостей Державного бюджету України покривати реальну вартість послуг. Тому через місяць фінансування вторинної ланки за новою схемою влада зрозуміла необхідність ґрунтовної корекції процесу реформування. Спочатку президент, а потім і міністр охорони здоров'я заявили про необхідність внесення численних змін до нормативно-правової бази реформи. Однак у зв'язку зі стрімким поширення пандемії COVID-19 жодних конкретних змін, покликаних корегувати впровадження медичної реформи, в юридичній площині зроблено не було, а вторинна ланка опинилась у підвішеному стані: з одного боку уряд відновив фрінансування закладів охорони здоров'я на дореформених засадах, а з іншого - реформу не скасували.

У ході медичної реформи до галузі охорони здоров'я введено нові терміни і положення: договір про медичне обслуговування за програмою медичних гарантій, де- кларація про вибір лікаря, який надає первинну медичну допомогу тощо. Усі ці трансформаційні процеси вимагатимуть кваліфікованого юридичного супроводу. Наприклад, новим правовим інструментом - декларацією, що з'явилась зі стартом медичної реформи в Україні, унормовуються договірні відносини між пацієнтом і лікарем із метою надання останнім медичних послуг. Підтримуємо позицію С. Книша [7, с. 380], що використання терміну "декларація" $€$ не зовсім юридично грамотним у контексті правовідносин у медичній сфрері. Більш доцільнішим було б використання терміна "договір", що укладається суб'єктами правовідносин у цій сфері. На офіційному сайті законодавець розмістив типову форму Декларації [13], що підписується пацієнтом і лікарем. Однак такий підхід звужує права пацієнта, оскільки позбавляє його можливості узгодити певні додаткові умови і тим самим унеможливлює договірний шлях розв'язання різних проблем між лікарем і пацієнтом. Окрім того, договірне регулювання суспільних відносин між пацієнтами і лікарем варто перенести і на відносини з іншими медичними працівниками: медсестрами, акушерами та ін.

Розглянемо форму Декларації про вибір лікаря, що пропонується законодавцем. Вона вимагає внесення великої кількості персональних даних. Окрім цього, електронна система охорони здоров'я зберігатиме відомості про стан здоров'я пацієнтів, перебіг лікування, медичне втручання тощо. Тут виникає проблема надійного захисту цих персональних даних. Доступ до них згідно з ч. 2 ст. 11 Закону № 2168-VIII можливий лише за згоди пацієнта чи його законного представника. Закон передбачає три випадки, за яких можливий також доступ до персональних даних без згоди пацієнта: 1) наявності ознак прямої загрози життю пацієнта; 2) неможливості отримання згоди такого пацієнта чи його законних представників (до часу, коли отримання згоди стане можливим); 3) за рішенням суду [12].

Відповідно до ч 2 ст. 11 згаданого закону, у разі, коли існує пряма загроза для життя пацієнта, його згода на доступ до персональних даних не $є$ обов'язковою. Однак у чинному законодавстві визначення поняття "прямої загрози життя" віднайти досить складно. Лише у Постанові Кабінету Міністрів України (далі - КМУ) "Деякі питання соціального захисту дітей, які перебувають у складних життєвих обставинах, зокрема таких, що можуть загрожувати їхньому життю та здоров'ю" від 03.10.2018 № 800 [14], є подібна дефініція. Таким чином, законодавчо неврегулюване поняття "пряма загроза життю" може слугувати підставою доступу до відомостей про пацієнта без його згоди. Тому з метою вдосконалення окремих положень Закону № 2168-VIII, до ч. 1 ст. 2 слід внести окремий пункт із конкретним визначенням поняття "прямої загрози життю".

Ще однією відчутною правовою проблемою у сфері охорони здоров'я $€$ відсутність чіткого нормативного закріплення прав і посадових інструкцій для керівників створених у ході медичної реформи некомерційних закладів охорони здоров'я. Наприклад, Постановою КМУ № 331 від 24.04.2020 р. [15] п. 1 передбачалось, що кошти, відведені на фінансування медичних послуг, пов'язаних із наданням медичної допомоги пацієнтам 3 COVID-19 за програмою державних гарантій, потрібно спрямовувати на здійснення додаткових доплат медичним та іншим працівникам закладів охорони здоров'я в розмірі до 300 \% заробітної плати. Однак уже керівництво некомерційних закладів охорони здоров'я визначає, розмір цих надбавок, хто та коли їх отримуватиме. У результаті медики, які перебувають на передовій боротьби з COVID-19 і щоденно ризикують життям і здоров'ям, отримують передбачені постановою кошти лише частково чи взагалі не отримують. Частиною окресленої 
проблеми є брак якісних управлінців у медичній галузі. Переймаючи досвід країн-членів Європейського Союзу з розподілу управлінських повноважень між генеральним директором, який займається основними адміністративними та господарськими питаннями, та медичним директором, відповідальним за медичні питання, МО3 України видало Наказ № 1977 від 31.10.2018 р. [16], в якому розділила функції директора та медичного директора. Від рівня компетентності керівників медичних закладів прямо залежить не тільки ефективність роботи установи, але й якість надання медичних послуг у ній. I доки медична реформа не отримала свого остаточного вигляду, державі необхідно цьому питанню приділити увагу, щоб позитивні зрушення від цих нововведень не обернулись катастрофою, коли керівники використовують кошти від НСЗУ не за призначенням, а на встановлення лише собі завищених окладів. У зв'язку із цим актуальності набуває питання підготовки і підвищення кваліфікації медичних працівників - адміністраторів та управлінців. Як обґрунтовано зазначає Т. Савіна, для вдосконалення підготовки, перепідготовки і підвищення кваліфікації медичних та управлінських працівників необхідно внести зміни і доповнення до чинної нормативно-правової бази [3, с. 124]. Оскільки вона носить абстрактний, загальноконцептуальний характер, а підзаконні акти досить часто не узгоджені між собою, то перш за все для вдосконалення нормативного забезпечення кадрової політики в галузі охорони здоров'я варто прийняти Концепцію розвитку кадрової політики у сфері охорони здоров'я [3, с. 123]. Також зазначимо про необхідність дотримання балансу між міжнародним досвідом і власними регіональними, соціально-економічними й іншими особливостями під час формування кадрової політики у сфрері охорони здоров'я [4, с. 86].

Важливим етапом реформування охорони здоров'я в Україні й оновлення законодавчої бази в цій галузі має стати впровадження лікарського самоврядування. У Верховній Раді України на розгляді перебував законопроєкт № 2445 від 14.11.2019 р. "Про самоврядування медичних професій в Україні" [17], який однак так і не було прийнято. Погоджуємося з думкою М. Аніщенка [6, с. 283], що головним його недоліком можна вважати наявність в органах лікарського самоврядування можливості ухвалювати рішення про доступ до медичної професії, оскільки це може призвести лише до посилення корупційної складової. Лікарське самоврядування повинно функціонувати як система незалежних громадських лікарських інституцій, з фуннціями захисту професійних прав медичних працівників і прав пацієнтів у разі їхнього порушення представниками медичних профресій, а також у разі недотримання ними норм медичної етики через діяльність дисциплінарних комісій

Не можливо обійти увагою і проблеми охорони здоров'я, які показала пандемія COVID-19. Боротьба з коронавірусом довела, що в Україні недостатньо вдало врегульовано епідеміологічний нагляд, інфекційний контроль і безпеку, існує величезна проблема з внутрішньолікарняним інфікуванням у зв'язку з відсутністю якісних протоколів і внутрішньогалузевих стандартів. Ще в лютому 2020 р., на порозі епідемії, на громадське обговорення було винесено проєкт наказу МОЗ "Про організацію профрілактики інфекцій та інфекційного контролю в закладах охорони здоров'я", однак цей документ так і залишається в статусі проєкту [18]. Крім того, короновірусна криза довела, що в Україні так і не відбулося належного становлення інституту громадського здоров'я. Також пандемія COVID-19 посилила проблеми 3 досягненням балансу між приватним і публічним інтересом, захистом персональних даних, нестачею донорської крові, лікарняних ліжок.
ВИСНОВКИ. Таким чином, ефективне реформування медицини, належний захист прав і свобод суб'єктів правовідносин у сфері охорони здоров'я, а як наслідок i збереження трудового потенціалу нашої держави неможливе без створення якісної правової бази. Удосконалення чинного законодавства у сфері охорони здоров'я ускладнюється комплексним характером правовідносин у зазначеній галузі й відсутністю стратегічних документів, які б визначали принципи, підходи, методи, концептуальні засади цього вдосконалення. Для розв'язання частини проблем, щонайшвидше потрібно прийняти новий зведений законодавчий акт із чітко визначеною внутрішньою структурою - Медичний кодекс України. Удосконаленню законодавства у сфері охорони здоров'я сприятиме внесення змін до норм, що регулюють питання захисту персональних даних, урегулювання епідеміологічного нагляду й інфекційного контролю для ефективної протидії пандемії COVID-19, прийняття закону про лікарське самоврядування, вироблення сучасних галузевих стандартів надання медичної допомоги. Дослідженням установлено, що відсутність стратегічних документів щодо підготовки медичних та управлінських кадрів, недосконала система кваліфрікаційних вимог, відсутність чітких посадових інструкцій для керівного персоналу $є$ основними проблемами кадрової політики у сфрері охорони здоров'я. Для розв'язання всіх зазначених проблем потрібно поєднати зусилля науковців і практиків у сфрері медицини і юриспруденції.

\section{Список використаних джерел}

1. Демченко І.С. Класифікація законодавства у сфері охорони здоров'я. Вчені записки ТНУ імені В.І. Вернадського. Серія: юридичні науки. Т. 30 (69) № 6 2019. С. 7-13.

2. Майданик Р. Законодавство України у сфері охорони здоров'я: система і систематизація. Медичне право. 2013. № 2 (12). С. 63-74.

3. Савіна Т.В. Нормативно-правове регулювання кадрової політики системи охорони здоров'я в Украйні. Політичні та правові аспекти державного управління. 2017. № 1. С. 120-128.

4. Короленко В.В., Юрочко Т.П. Кадрова політика у сфері охорони здоров'я України в контексті європейської інтеграції. К.: КіМ, 2018. 96 с.

5. Заморська Л. Право на охорону здоров'я: перспективи правового забезпечення. URL: https://law.chnu.edu.ua/pravo-na-okhoronu-zdoroviaperspektyvy-pravovoho-zabezpechennia/ (дата звернення 03.03.2021)

6. Аніщенко М.А. Основні тенденції сучасного реформування законодавства України у сфері охорони здоров'я. Актуальні питання фрармацевтичної і медичної науки та практики. 2020. Т. 13, № 2 (33). фармацевтич $278-287$.

7. Книш С.В. Адміністративно-правові відносини у сфері охорони здоров'я в Україні: дис. ...кан. юридичних наук: 12.00.07 / Тернопільський національний економічний університет. Тернопіль, 2019. 494 с.

8. Краснова О.І., Плужнікова Т.В. Особливості механізму державного регулювання сфери охорони здоров'я. Інвестиції: практика та досвіة. 2018. № 7. С. 46-48.

9. Швець Ю.Ю. Реалізація особою конституційного права на охорону здоров'я: порівняльно-правове дослідження: автореф. дис. ...док. юридичних наук: 12.00.02 / Державний вищий навчальний заклад "Ужгородський національний університет". Ужгород, 2019. 32 с.

10. Про визнання такими, що втратили чинність, деяких наказів Міністерства охорони здоров'я України: Наказ МОЗ України від 28.02.2020 № 590. URL: https://zakon.rada.gov.ua/rada/show/v059028220\#Text (дата звернення 03.03.2021).

11. Про внесення змін до наказу МОЗ України від 15.12.2003 року № 582 "Про затвердження протоколів з акушерської та гінекологічної допомоги": Наказ MO3 України від 27.12.2011 № 977. URL: https://zakon.rada.gov.ua/rada/show/v0977282-11\#Text (дата звернення 03.03.2021).

12. Про державні фрінансові гарантії медичного обслуговування населення: Закон України від 19 жовтня 2017 року № 2168-VIII. URL: https://zakon.rada.gov.ua/laws/show/2168-19\#Tеxt (дата звернення 03.03.2021).

13. Про затвердження Порядку вибору лікаря, який надає первинну медичну допомогу, та форми декларації про вибір лікаря, який надає первинну медичну допомогу: Наказ МОЗ України від 19.03.2018 № 503. URL: https://zakon.rada.gov.ua/laws/show/z0347-18\#n92 (дата звернення 03.03.2021).

14. Деякі питання соціального захисту дітей, які перебувають у складних життєвих обставинах, у тому числі таких, що можуть загрожувати їх життю та здоров'ю: Постанова Кабінету Міністрів України від 03.10.2018 № 800. URL: https://zakon.rada.gov.ua/laws/show/800-2018\%D0\%BF (дата звернення 03.03.2021)

15. Про невідкладні заходи щодо забезпечення державних фінансових гарантій медичного обслуговування пацієнтів з гострою респіраторною хворобою COVID-19, спричиненою коронавірусом SARS-CoV-2, та належної оплати праці медичних та інших працівників, які надають 
медичну допомогу таким пацієнтам: Постанова Кабінету Міністрів України від 24.04.2020 р. № 331. URL: https://zakon.rada.gov.ua/laws/ show/331-2020-\%D0\%BF\#Text (дата звернення 03.03.2021).

16. Про внесення змін до Довідника кваліфікаційних характеристик професій працівників. Випуск 78 "Охорона здоров'я": Наказ МОЗ України від 31.10.2018 № 1977. URL: https://moz.gov.ua/article/ministrymandates/nakaz-moz-ukraini-vid-31102018--1977-pro-vnesennja-zmin-dodovidnika-kvalifikacijnih-harakteristik-profesij-pracivnikiv-vipusk-78-ohoronazdorovja (дата звернення 03.03.2021)

17. Про самоврядування медичних професій в Україні: Проект Закону України від 14.11.2019. № 2445 URL: http://w1.c1.rada.gov.ua/pls/ zweb2/webproc4 1?pf3511=67395 (дата звернення 03.03.2021).

18. Про організацію профілактики інфекцій та інфекційного контролю в закладах охорони здоров'я: проект Наказу МОЗ від 12.02.2020. URL: https://moz.gov.ua/article/public-discussions-archive/proekt-nakazumoz-ukraini-pro-organizaciju-profilaktiki-infekcij-ta-infekcijnogo-kontrolju-vzakladah-ohoroni-zdorov\%e2\%80\%99ja (дата звернення 03.03.2020)

\section{References}

1. Demchenko, I.S. (2019) Klasyfikatsiia zakonodavstva u sferi okhorony zdorov'ia [Classification of health care legislation]. Vcheni zapysky TNU imeni V.I. Vernadskoho. Seriia: yurydychni nauky - Scientific notes of Taurida National V.I. Vernadsky University. Series: Juridical Sciences, V. 30 (69), 6, 7-13. [in Ukrainian].

2. Maidanyk, R. (2013). Zakonodavstvo Ukrainy u sferi okhorony zdorov'ia: systema i systematyzatsiia [Ukrainian Legislation in the Health Care Sphere: System and Systematization]. Medychne pravo - Medical Law, 2 (12), 63-74. [in Ukrainian].

3. Savina, T.V. (2017) Normatyvno-pravove rehuliuvannia kadrovoi polityky systemy okhorony zdorov'ia v Ukraini [Normative-legal regulation of personnel policy of the health care system in Ukraine]. Politychni ta pravovi aspekty derzhavnoho upravlinnia - Public Administration: Theory and Practice, 1, 120-128. [in Ukrainian]

4. Korolenko V.V., \& Yurochko, T.P. (2018). Kadrova polityka u sferi okhorony zdorov'ia Ukrainy $v$ konteksti yevropeiskoi intehratsii [Personnel policy in the field of health care of Ukraine in the context of European integration]. Kyiv: KiM. [in Ukrainian]

5. Zamorska, L. (2020) Pravo na okhoronu zdorov'ia: perspektyvy pravovoho zabezpechennia [The right to health care: prospects for legal support]. Retrieved from: https://law.chnu.edu.ua/pravo-na-okhoronuzdorovia-perspektyvy-pravovoho-zabezpechennia/ [in Ukrainian]

6. Anishchenko, M. A. (2020) Osnovni tendentsiï suchasnoho reformuvannia zakonodavstva Ukrainy u sferi okhorony zdorov'ia [The main tendencies of the current reform of the Ukrainian legislation in the field of health care] Aktualni pytannia farmatsevtychnoï i medychnoï nauky ta praktyky - Current issues in pharmacy and medicine: science and practice, V. 13, 2(33), 278-287. [in Ukrainian]

7. Knysh, S. V. (2019). Administratyvno-pravovi vidnosyny u sferi okhorony zdorov'ia v Ukraini [Administrative and Legal Relations within Health Care Sector in Ukraine.] (Doctoral thesis) Ternopil. [in Ukrainian].

8. Krasnova, O.I., \& Pluzhnikova, T.V. (2018) Osoblyvosti mekhanizmu derzhavnoho rehuliuvannia sfery okhorony zdorovia [Peculiarities of the state regulation mechanism of health]. Investytsii: praktyka ta dosvid Investment: Practice and Experience, 7, 46-48. [in Ukrainian].

9. Shvets, Yu.Yu. (2019) Realizatsiia osoboiu konstytutsiy̌noho prava na okhoronu zdorov'ia: porivnialno-pravove doslidzhennia [Realization of the constitutional right of a person to health care: comparative legal study.] (Extended abstract of Candidate's thesis). Uzhhorod. [in Ukrainian]

10. Pro vyznannia takymy, shcho vtratyly chynnist, deiakykh nakaziv Ministerstva okhorony zdorovia Ukrainy: Nakaz MOZ Ukrainy vid 28.02.2020 № 590. [On recognizing as invalid some orders of the Ministry of Health of Ukraine: Order of the Ministry of Health of Ukraine dated 28.02.2020 № 590]. Retrieved from: https://zakon.rada.gov.ua/rada/show/ v0590282-20\#Text [in Ukrainian]
11. Pro vnesennia zmin do nakazu MOZ Ukrainy vid 15.12 .2003 roku № 582 "Pro zatverdzhennia protokoliv $z$ akusherskoi ta hinekolohichnoi dopomohy": Nakaz MOZ Ukrainy vid 27.12.2011 № 977. [On amendments to the order of the Ministry of Health of Ukraine dated 15.12.2003 № 582 "On approval of protocols on obstetric and gynecological care": Order of the Ministry of Health of Ukraine dated 27.12.2011 № 977]. Retrieved from: https://zakon.rada.gov.ua/rada/show/v0977282-11\#Text [in Ukrainian].

12. Pro derzhavni finansovi harantii medychnoho obsluhovuvannia naselennia: Zakon Ukrainy vid 19 zhovtnia 2017 roku № 2168-VIII [On state financial guarantees of medical care to the population: Law of Ukraine of October 19, 2017 № 2168-VIII] Retrieved from: https://zakon.rada.gov.ua/ laws/show/2168-19\#Text [in Ukrainian]

13. Pro zatverdzhennia Poriadku vyboru likaria, yakyi nadaie pervynnu medychnu dopomohu, ta formy deklaratsii pro vybir likaria, yakyi nadaie pervynnu medychnu dopomohu: Nakaz MOZ Ukrainy vid 19.03.2018 № 503 [On approval of the Procedure for selection of a doctor who provides primary care and forms of declaration on the selection of a doctor who provides primary care: Order of the Ministry of Health of Ukraine dated March 19 , 2018 № 503]. Retrieved from: https://zakon.rada.gov.ua/laws/show/z034718\#n92 [in Ukrainian]

14. Deiaki pytannia sotsialnoho zakhystu ditei, yaki perebuvaiut u skladnykh zhyttievykh obstavynakh, u tomu chysli takykh, shcho mozhut zahrozhuvaty yikh zhyttiu ta zdorov'iu: Postanova Kabinetu Ministriv Ukrainy vid 03.10.2018 № 800 [Some issues of social protection of children in difficult life circumstances, including those that may threaten their lives and health: Resolution of the Cabinet of Ministers of Ukraine dated 03.10.2018 № 800]. Retrieved from: https://zakon.rada.gov.ua/laws/show/800-2018$\%$ D0\%BF [in Ukrainian].

15. Pro nevidkladni zakhody shchodo zabezpechennia derzhavnykh finansovykh harantii medychnoho obsluhovuvannia patsiientiv $z$ hostroiu respiratornoiu khvoroboiu COVID-19, sprychynenoiu koronavirusom SARSCoV-2, ta nalezhnoi oplaty pratsi medychnykh ta inshykh pratsivnykiv, yaki nadaiut medychnu dopomohu takym patsiientam: Postanova Kabinetu Ministriv Ukrainy vid 24.04.2020 r. № 331 [On urgent measures to provide state financial guarantees for medical care of patients with acute respiratory disease COVID-19 caused by coronavirus SARS-CoV-2, and proper remuneration of medical and other workers who provide medical care to such patients: Resolution of the Cabinet of Ministers of Ukraine 24.04.2020 № 331]. Retrieved from: https://zakon.rada.gov.ua/laws/show/331-2020$\% \mathrm{D} 0 \% \mathrm{BF \# Text}$ [in Ukrainian].

16. Pro vnesennia zmin do Dovidnyka kvalifikatsiinykh kharakterystyk profesii pratsivnykiv. Vypusk 78 "Okhorona zdorovia": Nakaz MOZ Ukrainy vid 31.10.2018 № 1977 [On making changes to the Handbook of qualification characteristics of employees' professions. Issue 78 "Health Care": Order of the Ministry of Health of Ukraine dated 31.10.2018 № 1977]. Retrieved from: https://moz.gov.ua/article/ministry-mandates/nakaz-moz-ukrainivid-31102018--1977-pro-vnesennja-zmin-do-dovidnika-kvalifikacijnihharakteristik-profesij-pracivnikiv-vipusk-78-ohorona-zdorovja [in Ukrainian]

17. Pro samovriaduvannia medychnykh profesii $\vee$ Ukraini: Proekt Zakonu Ukrainy vid 14.11.2019. № 2445[On self-government of medical professions in Ukraine: Draft Law of Ukraine of 14.11.2019. № 2445]. Retrieved from: http://w1.c1.rada.gov.ua/pls/zweb2/webproc4_1?pf3511=67395 [in Ukrainian].

18. Pro orhanizatsiiu profilaktyky infektsii ta infektsiinoho kontroliu $v$ zakladakh okhorony zdorov'ia: proekt Nakazu MOZ vid 12.02.2020 [On the organization of infection prevention and infection control in health care facilities: draft Order of the Ministry of Health of 12.02.2020]. Retrieved from: https://moz.gov.ua/article/public-discussions-archive/proekt-nakazu-mozukraini-pro-organizaciju-profilaktiki-infekcij-ta-infekcijnogo-kontrolju-vzakladah-ohoroni-zdorov\%e2\%80\%99ja_[in Ukrainian].

Received: $31 / 03 / 2021$

Accepted: 25/04/2021

\section{A. Kryzhevskyi, PhD (history), Assist., Junior Researcher \\ Taras Shevchenko National University of Kyiv, Kyiv, Ukraine}

\section{CURRENT ISSUES OF IMPROVEMENT OF UKRAINIAN LEGISLATION IN THE FIELD OF HEALTHCARE}

The article is dedicated to the issues of legal medical sphere regulation in Ukraine. The purpose of the article is to study current issues of improving the Ukrainian legislation in the field of health care, to identify existing problems and outline the ways to solve them.The study of legal phenomena and legal categories was carried out through using general and special legal methods of cognition, namely: classification method, modeling, specific-statistical, systematical-structural, comparative-legal, formal-legal, dialectical and other methods of scientific analysis according to the research subject. Conclusions. The article asserts that for the effective reform of the medical sector and for sufficient protection of legal entities rights and freedoms in the health care field, a high-quality regulatory framework is needed. It has been proven that the improvement of the current healthcare legislation is complicated by the complex essence of legal relations in this area and the lack of a clear and systematic approach. It is substantiated the expediency of passing the special consolidated legislative act with a clear internal structure - the Medical Code of Ukraine. The author proposes to amend provisions regulating the protection of personal data, epidemiological surveillance and infection control. The adoption of the law on medical self-government and development of modern industry standards for medical care is substantiated. The problems of industry staffing, as well as the lack of strategic documents for the training for health workers and imperfect instructions for managers of several health care institutions are analyzed. The author also identifies the main problems of personnel policy in the healthcare. The author specifies the necessity to unite the efforts of scientists and practitioners in the medicine and jurisprudence for solving all the individual problems on improving the regulatory framework in the field of health care.

Keywords: medical reform, healthcare, regulatory act, legislation, Medical code, medical self-government, medical standard, COVID-19, declaration. 